\title{
TIJD VOOR VERBINDING
}

door

Marian Adriaansen

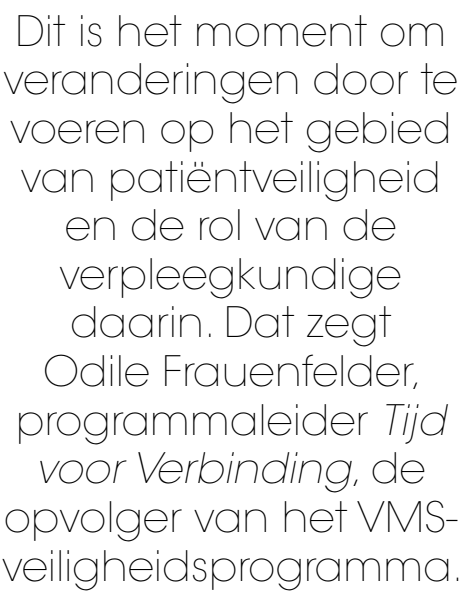

Dit is het moment om veranderingen door te voeren op het gebied van patiëntveiligheid en de rol van de verpleegkundige daarin. Dat zegt Odile Frauenfelder. programmaleider Tijd voor Verbinding, de opvolger van het VMSveiligheidsprogramma

\section{Wat is het programma Tijd voor Verbinding?}

'Vooral een netwerkorganisatie. Het is onze opdracht bestaande netwerken met elkaar in verbinding te brengen en nieuwe netwerken te laten ontstaan. Daarbij wil Tijd voor Verbinding goede praktijkvoorbeelden delen en instellingen helpen verbeteringen in te zetten. Zowel het VMS-veiligheidsprogramma als Tijd voor Verbinding is voortgekomen uit de Nivel-monitoring naar potentieel vermijdbare schade en sterfte in de medisch-specialistische zorg. Toen de eerste monitor uitkwam in 2004, schrok iedereen omdat er sprake was van veel vermijdbare schade en sterfte. De cijfers moesten omlaag, via een top-down gestart VMS-veiligheidsprogramma gericht op tien verbeterpunten en het opzetten van onderzoek- en verbetertrajecten naar aanleiding van calamiteiten, fouten en bijna-incidenten. Dit wordt ook wel Safety-I genoemd. In de volgende monitoring was bijna een halvering van de cijfers te zien. Maar de daling veranderde in een langzame stijging, zo bleek uit de monitor van 2017. Dat gebeurde onder andere bij de zorg rondom kwetsbare ouderen. Een ander item is medicatieveiligheid, waarop veel is ingezet en waar vorderingen zijn gemaakt. Maar bijvoorbeeld antistolling zorgde voor 38 procent van de medicatiefouten; dit heeft te maken met toegenomen complexiteit van deze medicatie en betrokkenheid van veel professionals met veel overdrachtsmomenten. De monitor liet ook zien dat verbeteringen in samenwerking en communicatie kunnen leiden tot betere zorg. Het goede gesprek. Dus er moest wel een vervolg komen op het VMS-veiligheidsprogramma.'

\section{Hoe zag dit vervolg eruit?}

'Volgens de toenmalige bestuurders van de vier betrokken VMS-zorg-branchepartijen (NVZ, NFU, V\&VN en FMS) was het plateau van Safety-I bereikt. Een volgende stap zou ingewikkelder worden, want die gaat over cultuurveranderingen. Het leervermogen van organisaties en goede praktijkvoorbeelden zouden voorop moeten staan en daar is de medisch-specialistische zorg nog niet zo aan gewend. Het vergt tijd voordat de positieve gevolgen van deze benadering waarneembaar zijn. Ook Patiëntenfederatie Nederland en zelfstandige klinieken zijn vervolgens aangehaakt. Uiteindelijk is daaruit Tijd voor Verbinding ontstaan, gericht op de thema's kwetsbare oudere, multidisciplinair gesprek en antistolling, en parallel daaraan Safety-II.'

\section{Safety-II?}

'Voor het thema Safety-II is bij ZonMw een onderzoeksprogramma gestart, gericht op het verkrijgen van wetenschappelijke onderbouwing van het "nieuwe" veiligheidsdenken en -werken. De onderzoekscalls zijn belegd bij ZonMw. De programma's werken nauw met elkaar samen. Kwaliteitsonderzoek is vaak kwalitatief onderzoek en gericht op narratieve en actiegerichte methodieken. Het gaat over het werk dat je als professional iedere dag doet en dat bijna altijd goed gaat, terwijl er dagelijks een ander team werkt en er nieuwe patiënten zijn. Hoe komt het dat we zoveel veerkracht hebben? Het is interessant om dat voor onze thema's te onderzoeken.

\section{Dat was voor de medisch specialisten even wennen}

'Binnen de Federatie Medisch Specialisten is het aandachtsgebied wetenschap en daarmee patiëntveiligheid en kwaliteit sterk vertegenwoordigd. Mijn wens voor de $V \& V N$ is dat dit andachtsgebied de komende jaren groeit en een stevig onderdeel wordt. We willen verpleegkundigen 


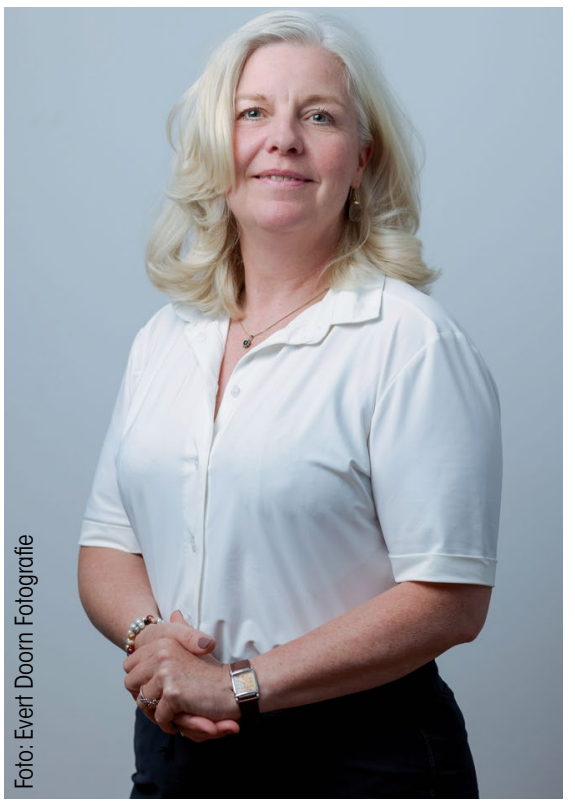

beter en prominenter positioneren. Hen echt het gevoel geven: jij hebt een goudmijn aan kennis en ervaring en je mág je meer uitspreken. En ontwikkelen! We hebben je nodig om de zorg te verbeteren.'

\section{V\&VN heeft zich op ontwikkeling van richtlijnen gericht}

'Zeker! Die wetenschap is hard nodig, maar slechts een klein gedeelte van wat wij doen is werkelijk bewezen. Ga ook uit van de kracht van alledag. In de afgelopen anderhalve jaar heeft Covid-19 een stempel gedrukt, maar we hebben laten zien hoe veerkrachtig de praktijk van alledag is. Op dit moment hebben wij er als programma wel last van dat de medisch-specialistische zorg vermoeid en overbelast is. Vooral verpleegkundigen hebben het zwaar.'

\section{Die verpleegkundigen vormen het ledenbestand van V\&VN}

'De hele zorg zit in een infarct. Toch denk ik dat dit ook juist het moment is om veranderingen door te voeren, zeker op het gebied van patiëntveiligheid en de rol van de verpleegkundige daarin. Dit programma gaat ook over regie, die terug moet naar de professional en patiënt. En als programmaleiding kijk ik vooral naar de consequenties die een cultuurverandering met zich mee kunnen brengen. Als je op een andere manier gaat werken, moet je misschien ook durven kijken naar andere manieren van verantwoorden en bekosti- gen. We willen in ieder geval niet meer registratielast veroorzaken. Daarom zoekt Tijd voor Verbinding verbinding met andere programma's, bijvoorbeeld (Ont)Regel de Zorg, om niet het wiel opnieuw te hoeven uitvinden'.

\section{Je zit in het regieteam}

'Ik ben programmaleider en het gezicht naar buiten. Mijn collega-programmamanager is de leidinggevende van het regieteam. Dat bestaat uit netwerkbouwers, veiligheidsadviseurs en communicatieadviseurs. Netwerkbouwers bezoeken de instellingen om het gesprek aan te gaan. Zij komen meestal binnen op kwaliteitsafdelingen en die hebben de insteek: wat moeten we opleveren? Maar wij vragen: wat hebben jullie nodig en waar zijn jullie trots op? We willen graag met verpleegkundigen, patiënten en medisch specialisten in gesprek over de dagelijkse praktijk. Waar zijn ze trots op en wat zouden ze graag willen veranderen? We zijn begonnen mooie voorbeelden te publiceren (programmatvv.nl). Niet alles is direct naar een andere instelling te vertalen, maar het moet een soort digitale kaartenbak worden met goede voorbeelden. We hebben ook filmmateriaal, een podcastserie en goed bezochte webinars over Safety-II. Ons programma moet natuurlijk ook worden gemonitord, maar cultuurverandering is moeilijk te monitoren, dus harde cijfers zijn niet passend. Als regieteam willen we naast de praktijkvoorbeelden ook via actieonderzoek inventariseren wat belemmerend en faciliterend is en of een initiatief reproduceerbaar is. Bij implementatie is het van belang te weten waarom het al dan niet werkt; anders gaat het nooit lukken.'

\section{Deze benadering lijkt logisch, maar} in de praktijk werkt het niet altijd zo. Hoe voorkom je het not invented here-syndroom: wij zijn anders en dus kan het $z 0$ niet werken?

'Het is behulpzaam dat de Inspectie Gezondheidszorg en Jeugd in overleg met de praktijk anders toezicht wil gaan houden; de IGJ gaat veel meer naar verbeterdoelen in samenspraak met de instellingen. Wij brengen instellingen met elkaar in contact en daar komen mooie samenwerkingen uit voort. Vaak gaat de samen- werking op professioneel niveau goed en kunnen verpleegkundigen de verbinders zijn. Ook patiënten kunnen helpen, want die worden steeds mondiger. Uit een onlangs gepubliceerde patiëntenuitvraag door Patiëntenfederatie Nederland blijkt dat jongere patiënten kritischer zijn; ze zijn bijvoorbeeld niet altijd tevreden over het standaardgesprek. Het thema multidisciplinair gesprek is niet alleen het gesprek van professionals onderling, maar gaat ook over hoe patiënten kunnen worden betrokken in de kwaliteitswereld van hun ziekenhuis.'

\section{Jullie zijn anderhalf jaar bezig. Wat beschouw jij als de voornaam- ste opdracht voor de komende periode?}

'Het kennisnetwerk moet worden uitgebouwd en overlap met andere programma's moet eruit worden gehaald. Met de kernopdracht die overblijft moet je de boer op: dit onze inspiratiebox. We willen instellingen helpen met implementeren. Als daar nieuwe vragen uit voortkomen, zullen we in onze aanbevelingen aan de brancheorganisaties, het ministerie van VWS en de politiek verduidelijken dat wanneer je die cultuurverandering nastreeft, een volgende stap moet worden gezet in bijvoorbeeld bekostiging. Wij kunnen alleen een aanzet geven, maar we kunnen niet op de oude manier verder. Samenwerking met patiënten en tussen disciplines onderling is een belangrijk onderdeel van een veilige zorgomgeving, waarbij professionals het gevoel hebben dat ze de regie weer in handen hebben.'

\section{Wat is je belangrijkste boodschap voor verpleegkundigen?}

'Ik zou het leuk vinden als verpleegkundigen en verpleegkundig onderzoekers meer bij ons aankloppen op het gebied van kwaliteit. Wij willen een podium bieden om te laten zien wat mensen nu al aan praktijkgericht onderzoek doen. Denk bijvoorbeeld ook aan de tweede call van ZonMw in 2022. Deze organisatie wil verpleegkundigen graag helpen met een subsidieaanvraag, want daar zitten soms mooie praktijkgerichte onderzoeken tussen die zinvol kunnen zijn voor de cultuurverandering die wij als programma willen helpen in gang te zetten.' 